This paper is published as: Yoon, Y. \& Chung, H. (2015/forthcoming) "New forms of dualization? Labour market segmentation patterns in the UK from the late 90s until the postcrisis in the late 2000s" Social Indicators Research.

\title{
New forms of dualization? Labour market segmentation patterns in the UK from the late 90s until the post-crisis in the late 2000s.
}

\author{
Yeosun Yoon $^{1} \&$ Heejung Chung \\ School of Social Policy, Sociology and Social Research \\ University of Kent, UK
}

\begin{abstract}
There has been an increase in literature that examines the patterns of dualization in labour markets across different welfare states. However, rarely do these studies empirically explore how labour markets are divided. Rather they assume a certain type of division to exist in a market, and apply this assumption to measure the extent to which this division can be observed. This paper aims to overcome this limitation by examining the labour market dualization patterns of the UK's employed population over the past decade through a latent class analysis model. Our analysis shows that the UK labour market could be characterised by a three group system during the period between 1999 and 2010. This divide supports the theoretical literature on labour market divisions in that there are clear distinctions between those who are insiders and those who are not. However, what is interesting is that rather than having a dichotomised pattern of division of insiders and outsiders, we find a third group which can be characterised as a "future insecure" group. What is more, the main characteristics that divide the groups are not contract types (involuntary part-time or temporary employment), but rather income levels(low pay), occupational profile (low-skilled occupations) and social security benefits stemming from employment (occupational pension coverage). From the results, we conclude that the patterns and characteristics of labour market divisions may not be generalised and further empirical investigations are needed to understand the cross-national variations.
\end{abstract}

Key words: labour market dualization, division patterns, UK, latent class analysis, longitudinal study

\footnotetext{
${ }^{1}$ Corresponding author: Yeosun Yoon, email: Y.Yoon@kent.ac.uk
} 


\section{Introduction}

The division of the labour force has become an important issue across many advanced industrial countries over the past decade. There has been a steep widening of income inequality between workers over the past couple of decades (OECD 2008; Kolev and Saget 2010). We also see a growth in atypical and precarious employments which are often characterised by low-pay, part-time working and contracts of limited duration (Kalleberg 2009; Vallas and Prener 2012). According to Standing (2011), a new social class, the precariat, is developing where precarious employment statuses are no longer a phase in one's life but a permanent state of employment and income insecurity. Such a division in the labour market is not, however, entirely a recent issue. Since the 1970s, when the full employment model began to erode, there have been an increasing number of studies that emphasise the trend of labour market divisions particularly linked with the widening income inequality, as well as the increasing unemployment (e.g., Reich et al. 1973; Gordon et al. 1982; Lindbeck and Snower 2002; Goos and Manning 2003).

The ways in which labour market divisions are defined, and the processes incorporated, however, vary in the exiting literature (Davidsson and Naczyk 2009; Rueda 2014). Some scholars view the divide as a distinction between those who are employed and those who are not (e.g., Lindbeck and Snower 1988, 1986) while others focus on the division within the employed population, based on security of income and stability of one's employment (e.g., Reich et al. 1973; Gordon et al. 1982; Goos and Manning 2003). A more recent literature on dualization proposes a wider concept of the division; i.e., those with a permanent, full-time contract against those with an atypical contract (temporary and involuntary part-time), or unemployed (Rueda 2006, 2007; Emmenegger et al. 2012b). However, the definition of who outsiders are have been disputed by others (Schwander and Häusermann 2013; Rueda 2014).

Despite the rather vigorous discussion regarding the definition and the developments of dualization, what is lacking in the literature is evidence on the actual patterns of labour market divisions across different countries. Most studies rely on pre-defined patterns and characteristics of market divisions based on theoretical understandings. They use these definitions to examine the extent to which divisions exist (Rueda 2006, 2007; Häusermann and Schwander 2012; Biegert 2014) or the stability of the segmented groups in certain countries (Blossfeld and Mayer 1988). However, not much research is done to empirically examine how labour markets are divided across different countries. Most studies are based on a presumption that certain employment statuses -e.g. unemployed, part-time, temporary employment contract, and low profile of occupations - are the major factors underlying the division in the labour market without providing clear empirical evidence to justify these claims. What is more, many studies examine the changes in institutional structures of countries that may provoke a change in labour market dualization patterns (Palier and Thelen 2010; 2012; Seeleib-Kaiser et al. 2012). In such cases, the analysis of the actual impact that institutional dualization has had on the labour market has been assumed yet not empirically examined. 
Another area that needs further attention is the variation in the patterns of labour market division between countries. Many studies agree that there are differences as to definitions of 'insider' and 'outsider' status, and thus as to who belongs to each segment, across countries (Esping-Andersen 1990; Davidsson and Naczyk 2009; Häusermann and Schwander 2009). However, most empirical studies on labour market divisions focus on specific countries, without addressing the limitations of applying one single definition of labour market divisions across different countries. For example, recent literature on labour market dualization primarily focuses on corporatist countries such as France and Germany and their increase in atypical employment and unemployment over the past few decades (Palier and Thelen 2010; SeeleibKaiser et al. 2012). Similar evidence for other countries is still lacking, and few studies systematically examine the labour market divisions in a way that allows for an exploration of country-specific patterns and features of divisions with empirical evidence. For example, not much attention has been given in analysing the distinctive characteristics of labour market divisions in liberal markets like the United Kingdom (UK) - which is the focus of this paper.

The UK is an interesting case since it is one of the countries where income inequality has risen most over the last two decades within Western Europe (OECD 2011). Much of this rise has been particularly due to the changes in the occupational and employment structure of the UK labour market. The number of low wage workers in the UK has also grown substantially over the last 20 years and has been highlighted as one of the key factors in widening labour divisions (Elias 1997; Bonoli 2007). Although a number of recent studies examine the UK, again in comparison to Germany (Tomlinson and Walker 2012; Biegert, 2014), the focus of their analysis does not lie in examining the distinct labour market division pattern of the UK. Tomlinson and Walker (2012) focus on the different outcomes of outsiderness (e.g., the recurrence of poverty) and Biegert (2014) examines how mobility patterns into and out of insider and outsider positions (defined by employment contract status) differ across different institutional regimes. Similar to the conclusions of Biegert (2014), we expect that patterns of dualization in the UK will vary from the patterns observed in corporatist/continental European countries because of its unique institutional settings and economic structure.

Lastly, there is also a lack of evidence to examine how labour market divisions have developed over time. According to Lindbeck and Snower (2002), the patterns of division in the labour market can change over time, and thus a certain degree of flexibility should be used in identifying the feature of division over time. The dualization literature also emphasises the growing level of division within the labour market over the past decade. Yet, there are limited number of studies that actually evaluate this growing gap between the divided labour force using quantified empirical data (Schwander and Häusermann 2013; Biegert 2014). In particular, there is a dearth of (recent) empirical studies that focus on the development of labour market divisions that explore the changing division patterns in the labour market as well as the volume of workers included in each segment.

Thus, the aim of this paper is to empirically explore the divisions in the UK labour market over 
the past decade, looking specifically at the employed population. Through this, we ask whether or not there are distinct labour market divisions in the UK, if such divisions are similar to what is assumed in the existing literature, and lastly to see whether the pattern of division has changed over the years. We make use of the British Household Panel Survey (BHPS) of 1999 to 2010, including cases from England, Scotland and Wales - excluding Northern Ireland. Through the application of latent class analysis models, we are able to find the patterns of labour market division and compare them over the past decade.

What our analysis shows is that the British labour market could be characterised by a three group system from 1999 and 2010. This divide supports the theoretical literature on labour market divisions in a sense that there are clear distinctions between those who are insiders of the labour market and those who are not. However, rather than a dichotomised pattern of division of insiders versus outsiders, we find a third group throughout the period of time under investigation. Interestingly, the division in the UK is not characterised by atypical employment contracts (involuntary part-time or temporary employment) as is normally assumed in the dualization literature. Rather, the division patterns in Britain are more defined by income levels (whether the workers are on low pay), occupational profile (occupational level) and social security stemming from the employment (occupational pension coverage). This provides further evidence to support the claim that labour market division patterns are diverse across different countries and provides a cautionary note as the limitations of measuring labour market dualization in a uniform manner.

In the next section the main theories behind labour market divisions as well as the relevance of the British case are examined. In the third section, the data and method of analysis are explained. The fourth section includes the analysis outcome and the paper ends with some discussion and conclusion.

\section{Theoretical perspectives on labour market division and the British context}

\section{Theoretical background}

Over the recent years, the growing literature on labour market dualization has reported a trend towards a division of the workforce between insiders and outsiders (e.g. Rueda 2006, 2007; Häusermann and Schwander 2009; Davidsson and Naczyk 2009; Emmenegger et al. 2012a; Rueda 2014). The literature on dualization conceptualises the bifurcated pattern of division between people who have permanent and full-time jobs (insiders) and those in atypical employment or unemployment (outsiders), focusing on continental European countries over the deindustrialisation period. However, the division of the labour force is not a recent phenomenon (Schwander and Häusermann 2013). The non-homogeneous characteristic of labour force was recognised from the 1960s with the persistence of income inequality in the 
US (Leontaridi 1998). Dual labour market and labour market segmentation theories highlighted the division among the employed labour force in the US labour market during the 1970s (Doeringer and Piore 1971; Reich et al. 1973; Gordon et al. 1982). According to them, the employed population is divided into a primary and secondary labour market based on their different working conditions, such as different level of employment and job security, career advancement prospects, and income levels. Similarly, the insider/outsider theory, which provides a foundation to the dualization theory, examines the dividing line between the employed and unemployed in the US during the sharp rise in unemployment from the oil shock in the early 1980s and the persistence of high unemployment levels in the late 1980s (Lindbeck and Snower 1988). In their later study, the definition of outsiders has been broadened to people with part-time or temporary contracts, i.e., those without employment stability (Lindbeck and Snower 2001). To sum, despite the varying definitions of labour market division across different scholars, employment/job instability and income insecurity have often been crucial factors to examine the labour market division.

However, many scholars have lately criticised the use of income and employment characteristics - namely the level of income or the type of employment contract/unemployment statuses - in defining the division of labour. Chung (2013) examines employment insecurity perceptions of insiders and outsiders, as defined by those with and without permanent contracts, across 23 European countries. Large cross-national variance was found in the relative insecurity temporary workers felt about their labour market positions compared to permanent workers, where in some countries no clear division was found in subjective insecurities. This provides evidence to as to how employment contract type alone may not be sufficient in examining labour market divisions. Schwander and Häusermann's (2013) main criticism stems from the fact that employment contract statuses are not stable, and may change frequently over time. Alternatively, they propose the use of occupational classes interacted with age and gender to identify labour market divisions which can represent stable employment biographies for each group over their working life. Biegert (2014) also criticises the use of atypical contract status at one given time as a proxy for outsiderness, in that this approach does not allow for the examination of the mobility patterns into and out of insider and outsider positions. He, thus, looks at transition patterns of workers into insider (permanent/full-time) positions and outsider (atypical employment or unemployment) positions using longitudinal data for Germany and the UK.

Nevertheless, all studies mentioned rely heavily on a theoretical assumption of the divisions in the labour market rather than any empirical investigation as to which factors can best define existing patterns of division. This is especially problematic when we consider the fact that labour market division patterns in one country may not necessarily reflect division patterns in others. For example, comparing the UK to Germany, Biegert (2014) comes to the conclusion that the insiders in Germany are in a much more stable position compared to those in the UK, due to the difference in the institutional structure of the two countries. Similar to the argument of Biegert, we maintain that institutional contexts may change the nature of insider position. 
However, going further, we also argue that the definition of insider and outsider positions will also vary largely depending on the institutional and market context of the country.

Furthermore, much of the existing literature assumes that divisions in the labour market remain persistent over time. This is especially thought to be so since there is a limited chance for mobility between the labour segments with barriers among the divided groups (e.g. Reich et al. 1973; Lindbeck and Snower 1988). Additionally, the recent literature on dualization suggest a widening division between the labour segments in many advanced countries over time (Häusermann and Schwander 2012; Rueda 2014). However, few studies empirically track the changing pattern of the division over time. Rather, the studies that look at changes overtime focus mostly on the changes in the institutional arrangements or labour market policies that affecting divisions of labour market (Seeleib-Kaiser et al. 2012; Palier and Thelen 2012). Other studies have examined the proportion of workers in outsider markets in certain countries over time (Eichhorst and Marx 2011). However, to the authors' knowledge, there is yet to be an examination of how division patterns change over time. Thus, more studies are needed that look at changes in the patterns of labour market division with a long-term perspective.

To sum up, many studies have examined the issue of labour market division theoretically as well with empirical data (e.g. Bulow and Summers 1986; Coe 1990; Blanchflower et al. 1990; Häusermann and Schwander 2012; Schwander and Häusermann 2013). However, most empirical studies analyse division of the labour market based on employment contract types reflected from theoretical assumptions, without exploring whether employment contract types are the actual driving characteristic of the divided labour market. Relying on a theoretical definition of division patterns in the market has the limitation of not being able to capture the varying patterns of labour market division across time and space, i.e., countries. We expect that the characteristics that drive division patterns in the labour market may vary across different countries and across time due to the varying institutional contexts and economic conditions. This paper will test whether this is the case through looking at the case of the UK across the past decade.

\section{The British context}

Notwithstanding debates on the concept of welfare regime typology, particularly the impurity of classification and ambiguity of criteria (Ferragina and Seeleib-Kaiser 2011; Van Kersbergen and Vis 2013), the UK is often described as a liberal welfare state. The welfare system in the UK is means tested and only compensates labour market disadvantages for the lowest strata of the labour market (Esping-Andersen 1990, 1999), with very meagre benefit levels and social assistance. Employer-provided benefits such as an occupational pension are used to supplement and complement welfare provisions (Seeleib-Kaiser et al. 2012). Also the economic and political ideology underlying liberal market economies (LMEs) is that national political 
economies are shaped based on competitive market arrangements (Hall and Soskice 2001). Thus, compared to other corporatist countries, its labour market regulations are less stringent and bargaining structures are based on company level negotiations rather than at a sectoral or country level (OECD 1999; Hall and Soskice 2001; OECD 2004). Furthermore, in the recent decades, deregulatory employment policies and competitive relations became key elements of UK's labour market strategies (Deakin and Reed 2000; Bonoli 2007).

Such characteristics have major and distinct consequences for its labour market structures as compared to other European countries. The level of involuntary part-time and temporary employments in the UK has been relatively low compared to other European countries (Green 2007; Bradshaw et al. 2010). For example, $6.3 \%$ of employees were in temporary contracts and $12.3 \%$ of part-time employees were involuntary part-time employment in 2012 (OECD 2013). One of the reasons behind this low number of atypical contracts is due to the low employment protection in the UK. The relative ease of firing workers makes temporary contracts less attractive to British employers compared to other corporatist countries with more stringent regulations (Dolado et al. 2002; Davidsson and Emmenegger 2013; Pavlopoulos 2013). In the case of individual lay-offs, open-ended contract workers with short tenures can be fired immediately (1 year before 2012, and 2 years afterwards) without any obligation of the employer to provide a justification. Thus, this enables employers' flexibility not through atypical contracts, but through the use of open-ended contracts with shorter tenure (Green 2007). In fact, the British market can be characterised as having high numbers of workers with unstable jobs, i.e., less than one year tenure, even compared to countries with a higher number of temporary contracts (see Chung 2005)

Another core element of the UK labour market is the high levels of income inequality. The UK has been noted as a country that experienced a faster growing level of earning inequality than any other OECD countries since 1975. It has also one of the large gaps between the top and bottom income deciles (OECD 2011). Thus, in comparison, the issue of job instability and income insecurity is particularly acute for those in low-paid and low-skilled jobs (Gregg 1997; Machin 2011). This is partly due to the fact that the employment distribution in the servicebased economy is often developed with the dichotomised pattern between high skills and high wage employment and low skills and low wage activities (Gregg and Wadsworth 2011). What is more, the liberal labour market settings and deregulated employment policies which particularly developed from the 1980s seem to accentuate the high economic inequality in the UK labour market (Deakin and Reed 2000). In fact, one of the most prevailing problems within the UK labour market is the proportion of working poor without adequate income levels and low wages in general (Bennett 2014). Moreover, many studies report that upward mobility, in terms of occupation and wage levels, has been reduced over time in the UK (Deakin and Reed 2000; Bonoli 2007; Machin 2011). Pavlopoulos et al. (2012) further argue that the low wage mobility in the UK is much worse than originally believed, and that there is little possibility of transition from the low pay to high pay segments for most workers. 
Although some earlier studies have examined the UK as an example of an economy where labour market segmentation patterns can be observed (Goos and Manning 2003; Marsden 2007), it has rarely been examined in the more recent studies that investigate labour market dualization patterns. For example, Tomlinson and Walker (2012) examine the British case compared to Germany, yet focusing on the at-risk poverty rate of outsiders - as defined again through employment contract statuses. Much of the existing literature on dualization has looked at social democratic countries (Rueda 2005, 2006) or the corporatist countries such as Germany and France (Palier and Thelen 2010; 2012). These countries are seen to be more likely to become dualized compared to other countries due to their distinctive institutional structures, such as a strong corporatist bargaining structure or the presence of a strong social democratic party. On the other hand, due to the flexible nature of labour market institutions, along with the relatively weak positions of unions, it is often assumed that labour market dualization is least likely to occur in liberal economies (Schwander and Häusermann 2011; Rueda 2012). The UK, thus, provides a critical case, a country where dualization is least likely to occur: if we can find a dualized pattern in the UK's labour market, it can act as a strong evidence to support the claim that labour market dualization is prevalent in different types of economies.

In addition, due to the distinctiveness in its institutional settings, the UK can be the case where commonly used division patterns - such as atypical contracts - may not be applicable when measuring labour market divisions. If the pattern of labour market division in the UK mirrors that of the corporatist countries, this will provide support in the application of atypical contracts as the major dividing line within the labour market when analysing dualization patterns across a larger group of countries. If the patterns of division deviates from the ones with corporatist countries the empirical results derived from the UK case may provide a good starting point in understanding the diverse labour market division patterns in different economies, especially within liberal economies. Since institutional structures vary even among the liberal welfare states (Ferragina and Seeleib-Kaiser 2011; Ferragina et al. 2015), the patterns found in the UK may not necessarily be generalizable for all liberal economies. However, there are still more similarities between liberal countries especially compared to the corporatist economies, and the results of this study will be helpful in building our understanding of these cases.

\section{Developing a measurement of labour market divisions: theoretical understanding of the division}

The main aim of this paper is to investigate the different patterns of labour market divisions in Britain through empirical data. Following the existing literature that places employment and/or income security as crucial elements in measuring disparities in the labour force, this paper incorporates a range of different income and employment characteristics. These are: low wage status, occupational level, and access to social security(namely occupational pensions).In addition, we add the commonly used operationalisation of market division as defined through 
employment contract types - i.e., temporary and part-time contracts. ${ }^{2}$

Most dualization literature emphasise the insider-outsider divide based on different degrees of employment stability, i.e., outsiders are those with atypical forms of contract due to their precariousness with employment stability. Such atypical forms of employment often include involuntary part-time work (working less than $30 \mathrm{hrs}$ per week involuntarily) and nonpermanent employment (those on contracts of limited duration), such as seasonal, temporary and fixed-term contracts (Rueda 2007, 2012; Häusermann and Schwander 2012; Emmenegger et al. 2012b). Although some scholars argue that temporary contracts can also serve a purpose of stepping stone into permanent work (Booth et al. 2002; Gebel 2010; Pavlopoulos 2013), it can be rather different between countries due to institutional and labour market contexts. In addition to part-time workers and temporary workers, those who are unemployed and students are also often defined as outsiders due to their precarious positions (Rueda 2007; Emmenegger et al. 2012b). However, we only focus on the employed population and their division patterns in this paper. Thus these groups are excluded from our analysis.

We also include occupational levels in the measurement model. In a recent study, Schwander and Häusermann (2013) argued that occupational profiles can explain the insider-outsider divide more stable than the precarious employment indicators. This is because occupational classes can trace employment trajectory of individuals, and thus provide long-term perspectives of employment paths, whereas contract types and income levels only take into account the worker's position at one given time.

Most dualization scholars exclude income levels when examining labour market division patterns (e.g., Rueda2005; 2007; Emmenegger et al. 2012), assuming that the characteristics of atypical employment can also capture potential income insecurity. However, dual and segmented labour market theory (e.g. Doeringer and Piore 1971; Reich et al. 1973), and recently Häusermann and Schwander (2012), point out that gaps in income levels can be a defining point in distinguishing divisions in the labour market. In addition, and as mentioned, income insecurity and inequality are major components that define the UK labour market, especially over the past decade. Furthermore, there has been extensive research and evidence on the extent of low wage (Sloane and Theodossiou 1996, 1998; Cappellari 2002; Cappellari and Jenkins 2004) and the limited chance of upward mobility for low-income strata in the UK, which has contributed greatly to the general rise of labour market divisions (Branden 2009). For example, the transition probability from the low pay to higher pay in the UK labour market has been noted to be lower than that of Germany (Pavlopoulos et al., 2013). Thus, we expect income levels, especially low-wages, to be a significant factor in explaining the division pattern

\footnotetext{
${ }^{2}$ Considering the low level of employment protection in the UK labour market, we also considered including tenure data into the analysis, but it did not lead to meaningful results and thus is excluded from the final model. However, detailed results of this model can be provided upon request. 
in the UK market, thus we include it to our measurement.

Another aspect we examine is the dualization patterns in relations to social security/policy. Palier and Thelen (2010) note that dualization has not only been restricted to labour market positions in terms of contract types, it has also led to dualization of social policy. In the case of UK, occupational pension coverage is important to consider, especially in its role of securing income for the future. In the UK, the replacement rate of the basic state pension scheme is fairly meagre so that occupational pensions have a more substantial effect on income during retirement (Blake 2004; Schwander 2010). The access to occupational pensions is directly linked with employment statuses unlike other social security benefits - such as unemployment benefit (Job Seeker's Allowance) which has a stronger means tested element to it. Thus, occupational pension access provides a view on how much future income security a worker can gain through their employment. In other words, we expect that the unequal access to occupational pension can contribute to an increasing dualization in the British welfare system. Thus, it can be an important indicator to include for distinguishing labour market positions within the UK market.

\section{Data and Methods}

\subsection{Data and variables}

This paper uses data from the BHPS from 1999 to 2008 and Understanding Society data for2010. The BHPS was launched in 1991 as the UK's first socio-economic household panel survey. It ended in 2008 with the start of the new panel, Understanding Society (University of Essex2013). Almost 6,700 of just over 8,000 BHPS participants in 2008 were incorporated into the Understanding Society Panel in 2010. As both surveys have been designed as a longitudinal survey, and followed the same representative sample of individuals annually, both are useful for exploring trends in labour market division (Jenkins 2010; Taylor et al. 2010). The sample consists of dependent employees across Britain between 1999 and 2010. In order to explore a clear pattern of labour market divisions among active workers over a decade, we examine the data from 1999 when the additional Scotland and Wales samples are added into the panel data. Northern Ireland is excluded in this study as this data was added in 2001. On average, the ratio of employees to the total labour force is 50 per cent and the actual sample size of each year includes around 5,000 individual employees throughout the period of time which can be a representative sample size of the population. ${ }^{3}$

In order to capture the distinctive pattern and characteristics of labour market divisions the

${ }^{3}$ The detail information about the overall sample size and proportion of active employees is from xjbstat variable in BHPS and $\mathrm{x}_{\_} \mathrm{jbstat}$ variable in Understanding society. 
analysis includes four sets of indicator (dependent) variables, as noted in the previous section (atypical employment status, occupation, wage and occupational pension coverage).Table 1 provides frequencies for these items for the past decade. Of the various years, we have included 1999, the first year where data is available to represent England, Scotland and Wales, 2010, the last year the data is available, and 2005, a pre-crisis year and a middle range year of our data set.

Atypical employment status is represented through two different variables: involuntary parttime employment and non-permanent employment. Involuntary part-time employment is recorded by combining the answers to two questions: the first asks about satisfaction with hours worked, the second is regarding whether one is working full-time or part-time. For the satisfaction of working hours variable, individuals could answer in a seven point scale from not satisfied at all (1) to completely satisfied (7). The latter is measured dichotomously, with two answer categories, i.e., working full-time or part-time. We combine these two questions and define involuntary part-time work as those who were on part-time jobs and answered that they are not satisfied with their working hours (less than three out of a scale of seven). The other category in the involuntary part-time variable is those who are in full-time jobs or voluntary part-time employment (computed as those who were on part-time jobs and satisfied with their working hours). For the temporary employment variable, we use the question regarding whether employee's current job is permanent or not permanent as binary options.

We used the International Standard Classification of Occupations (ISCO) to distinguish workers' occupational statuses. However, we found the nine occupational groupings to be too specific to capture the occupational biography of individual workers. Thus, the variable is recoded into 4 majors groups, as put forward by Schwander and Häuserman (2013) and supported by the ILO's four occupational classes (ILO 2012). The resulting group includes, Professional/Managerial, Associate professional/Associate managerial, Generally/ Vocationally skilled, and Low/Un-skilled workers. ${ }^{4}$

The analysis also includes information on wage, more specifically whether the workers are on low-pay or not (binary variable). We follow the Resolution Foundation's core definition on low pay - hourly wage below two-thirds of the gross median hourly pay for all employees (Pennycook and Whittaker 2012). The (annual) median hourly wage is extracted by first generating annual pay, measured through the use of the usual gross pay per month variable*12. This is then divided by the annual hours worked, generated through the normal working hours per week variable *52. Then, the two-third of median hourly wage is calculated from the hourly wage variable and those who fall under this amount are considered to be workers on low-pay and those who are above this threshold are categorised in non-low-pay category.

Access to occupational pension is measured as a dichotomous variable through the question

${ }^{4}$ See Appendix table 1 for categorisation. 
asking respondents if they have occupational pension based on the condition that employer runs an occupational pension scheme. Those whose employers do not run an occupational pension scheme (on average 30 per cent of total sample over time), or those who are not covered by the pensions scheme even when the employers run it, are considered to be those without occupational pension. In contrast, those who have occupational pensions through their work are categorised as those with occupational pension access.

\subsection{Method of analysis}

The pattern and characteristics of divisions in the UK labour market are derived through latent class models. Latent class analysis (LCA) models are statistical methods used to identify a presence of an unmeasured variable within a set of multivariate categorical data (McCutcheon 1987; Mejlgaard and Stares 2012). Thus, LCA enables us to find a number of exclusive and exhaustive subsets of individuals defined by the unobserved latent factor (the labour market division), named latent class from a set of observed variables (the four sets of individual's labour market characteristics). LCA is a person-centred approach compared to the variablecentred structural equation modelling techniques, and could thus be considered more holistic (Van Aerden et al. 2014; Lee et al. 2014). An increasing number of studies apply LCA to derive meaningful groupings of, for example, workers as classified by their working conditions (Van Aerden et al., 2014), individual's by their living conditions (Rose et al. 2009) or personalities (Lee et al, 2014), and firms based on their working time practices (Chung et al. 2007; Kerkhofs et al. 2008)

We start from the idea that there is not just one competing market, but a divided labour market which can be characterised by different level of employment stability and income security which are distinguished by the employment contract statuses, occupational classes, wage levels, and access to occupational pensions. Since our analysis focuses on identifying the pattern of labour market divisions and characteristics of each labour segment across the different time points, we use the BHPS data from 1999 to 2010 as sets of cross-sectional data. Also one of our aims of this paper is to find out the cross-time comparisons of labour market divisions, the multi-group LC modelling is considered to be the most appropriate approach (Figure1). ${ }^{5}$ Using different time points as a covariate in pooled cross-sectional data set from 1999 and 2010, we can formally assess a general pattern of labour market division over the last decade and a statistical significance of the variations in the pattern of divide across the different time points since the distribution of divided labour groups can vary depends on the cohort differences. This analysis also models the data as a finite mixture of distribution that each individual is placed on one of the latent groups (Dean and Raftery 2010) so we can estimate the size as well as the

\footnotetext{
${ }^{5}$ Formal specification (equation) of multi-group latent class model is further explained in the appendix.
} 
characteristics of each labour segment.

Figure 1.Multi-group Latent class model of labour market divisions

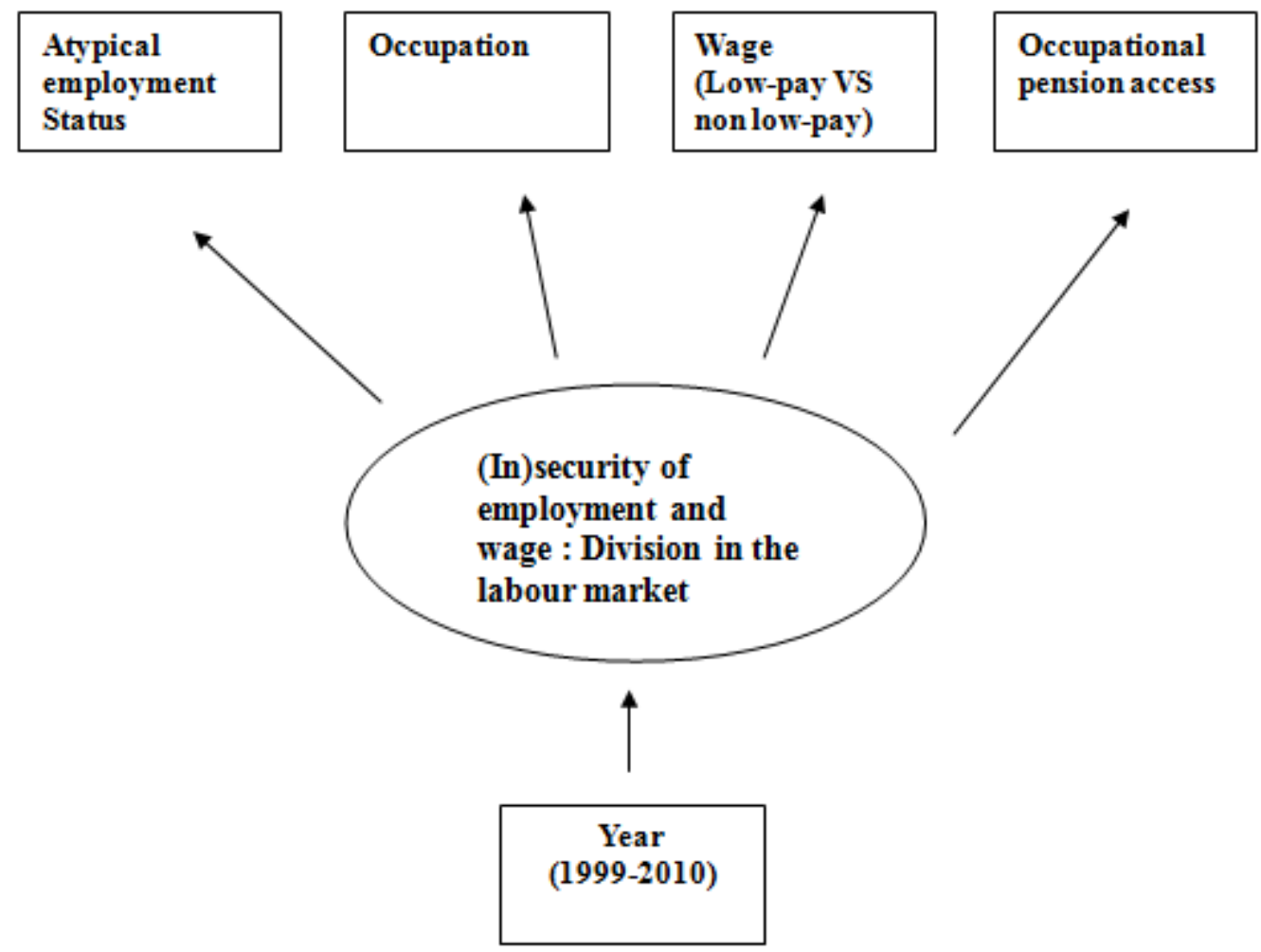

The model assessment for latent class models -that is finding the appropriate number of latent classes - can be often determined by comparing the statistical fit indices with an increasing number of classes. The comparative information criteria (IC), such as Akaike's information criterion (AIC) and the Bayesian information criterion (BIC), are frequently used to select the best fitting model: the model with the lower value being the better fit (Nylund et al. 2007; Gerber et al. 2009). We used both the AIC and the BIC for assessing the model fit. However,it is worth noting that they do not always agree on which is the "better" model and provide no information on the absolute fit of the model, especially with time points as a covariate (Mejlgaard and Stares 2012). ${ }^{6}$ As such, we also check two-way marginal residuals to view the model fit both for overall models and also condition on time points so as to gauge where the best and worst fit is over the last 10 years. It is often considered that if marginal residual greater

\footnotetext{
${ }^{6}$ In addition to the statistic describing the proportion of large two-way marginal residuals, we include other conventional statistics: the likelihood ration chi-squared statistics(L2) and number of degrees of freedom for the model and corresponding bootstrapped $p$-value,
} 
than 4 it suggest the poor fit (Bartholomew et al. 2008), but there are no absolute published guidelines on what percentage of large residuals indicates the dividing line between well-fitting and poor fitting models (Mejlgaard and Stares 2012).We therefore take account of statistical, practical, and theoretical considerations in the interpretation of our analyses. The characteristics of the divided labour groups are outlined by evaluating the patterns of conditional item response probabilities, representing the likelihood endorsing specific categories/characteristics of the indicator variables given a specific class membership. Then, we label the class accordingly based on our theoretical assumptions and interpretation of what the response profile indicates.

In keeping with the exploratory nature of the analysis, we formally assess the pattern of division with the four sets of indicator variables, which were constructed based on theoretical understanding of labour market divisions. However, we evaluate the model fit and check the robustness of our measurement model in order to measure the patterns of labour market divisions more correctly with the observed variables. We run the models using Mplus 6.1 mixture modelling function with maximum likelihood (ML) estimations (for technical details, see Muthén and Muthén 1998-2010) and other data management are done in R (R Core Team 2014).Via ML estimation, missing values within the observed variables are treated at random (Little and Rubin 2002)

\section{Results}

\subsection{Descriptive statistics}

First we examine the descriptive statistics on the distribution in the different employment contract statuses, wage, occupational level and occupational pension coverage as shown in Table 1. During the period 1999 to 2010, the size of non-permanent workers and involuntary part-time workers as a proportion of the total dependent employment are not large and have not changed much, with approximately $5 \%$ of the dependent employed in temporary contracts and $2 \%$ in part-time contracts throughout the period of investigation. Such figures are relatively similar to the OECD statistics for the UK with an average incidence of 6\%(temporary employment) and $2.5 \%$ (involuntary part-time employment). The proportion of low-pay workers has remained relatively stable over time as well, with between $17 \%$ and $18 \%$ of the surveyed employed population. The OECD statistics for the UK show slightly higher incidence rate of low-pay with an average 20\% during this same period but remaining stable over time. The level of the professional/managerial group has shown a gradual increase while the generally/vocationally skilled and low/unskilled group decreased slightly during the last 10 years. This may reflect the decline of the manufacturing industry and the expansion of skilled service sector within the UK labour market. Nonetheless, the generally/vocationally skilled group is the largest group within the occupational classes. In terms of occupational pension 
coverage across time, there has been a slight increase in the accessibility of occupational pensions although almost half of the total dependent employed population are not covered by the occupational pension programme in 2010.

Table1. Basic frequencies of item responses between 1991 and 2010 (\% dependent employed)

\begin{tabular}{lllll}
\hline Variable & & $\mathbf{1 9 9 9}$ & $\mathbf{2 0 0 5}$ & $\mathbf{2 0 1 0}$ \\
\hline Atypical contract & & & & \\
\multicolumn{1}{c}{ Permanency of contract } & Permanent worker & 94 & 96 & 94 \\
& Non-permanent worker & 6 & 4 & 6 \\
Number of hours & Full-time \&voluntary part-time worker & 98 & 98 & 97 \\
& Involuntary part-time worker & 2 & 2 & 3 \\
Pay level & Non-low pay worker & 82 & 83 & 82 \\
& (> 2/3 of median hourly wage) & & & \\
& Low pay worker & 18 & 17 & 18 \\
& (<2/3 of median hourly wage) & & & \\
Occupational profiles & Professional/managerial & 20 & 21 & 23 \\
& Associate professional/managerial & 19 & 21 & 20 \\
& Generally/vocationally skilled & 44 & 44 & 42 \\
& Low-unskilled & 17 & 14 & 15 \\
Occupational pension & Workers with occupational pensions & 53 & 54 & 55 \\
& Workers w/out occupational pensions & 47 & 46 & 45 \\
\hline N & & 7072 & 6727 & 4693 \\
\hline
\end{tabular}

\subsection{LCA groups}

By conducting an exploratory latent class analysis, we observed that there is clear support for a segmented labour market in the UK between 1999 and 2010. Table 2 describes fit statistics for a set of joint period models between 1999 and 2010, the best model is marked in bold, i.e., the three-class model. From the relative fit statistics, the fit improves by increasing the number of classes, but the results for four and five class models do not provide meaningful groups as one of the subgroups in the four-class and two subgroups in the five-class solution account for a very small proportion, less than 3 per cent of total sample throughout the years. ${ }^{7}$ Statistically and practically, the three-class result is found to be most reliable, and is therefore is chosen as

\footnotetext{
${ }^{7}$ The labour segment with less than 3 per cent of total sample can be considered as a non-identified segment since it is too small to be representative as a single group especially when comparing the pattern of segment conditional on different time points 
our preferred cross-time point (1999-2010) model of labour market division.

The three group result deviates from the assumed labour market division patterns posited by scholars of dual labour market theories and dualization theory where a two group division is expected. However, such a varied pattern of labour market segmentation has been found in previous studies in other countries. For example, Blossfeld and Mayer (1988) - using indicators of occupational characteristics- suggested that West German labour market consists of four different labour groups, and Jessoula, Graziano and Madama (2010) identified three labour segments in Italian labour market using indicators of the different types of employment contracts and their job protection levels.

Table2. Fit statistics for pooled cross-wave(year) models between 1999 and 2010

\begin{tabular}{|c|c|c|c|c|c|c|c|c|c|c|}
\hline \multirow[t]{2}{*}{$\begin{array}{l}\text { No. of } \\
\text { classes }\end{array}$} & \multirow[t]{2}{*}{$\mathrm{L} 2$} & \multirow[t]{2}{*}{ d.f. } & \multirow[t]{2}{*}{$\mathrm{P}$} & \multirow[t]{2}{*}{ AIC } & \multirow[t]{2}{*}{$\mathrm{BIC}$} & \multicolumn{2}{|c|}{$\begin{array}{l}\% \text { two-way } \\
\text { residuals }>4\end{array}$} & \multicolumn{2}{|c|}{ standardised } & marginal \\
\hline & & & & & & Overall & Mean & Median & Min & Max \\
\hline 1 & - & - & - & 626810 & 627058 & 82 & - & - & - & - \\
\hline 2 & 636 & 48 & $<.001$ & 366223 & 366360 & 64 & 40 & 39 & 32 & 52 \\
\hline 3 & 385 & 40 & $<.001$ & 365513 & 365725 & 41 & 36 & 36 & 30 & 43 \\
\hline 4 & 218 & 32 & $<.001$ & 365270 & 365555 & 34 & 31 & 30 & 23 & 41 \\
\hline 5 & 123 & 24 & $<.001$ & 365173 & 365408 & 36 & 31 & 30 & 23 & 41 \\
\hline
\end{tabular}

Assuming that the UK labour market is divided into three different segments over the last 10 years, Table 3 presents the best joint model across the time period between 1999 and 2010 . Each latent group is represented by a column and each item response by a row. The distinctive characteristics that help us describe the classes are marked in bold. In the first group, the respondents are most likely to have stable employment positions, i.e., their probability of being in the permanent employment (98\%) and full-time or voluntary part-time employment (99\%) is very high. This group is also very likely to have an income above the low-pay threshold with a probability of $99 \%$. Workers in this group are either high or vocationally skilled (with a 55\% chance of being either professional/managerial or associate professional/managerial). Most are likely to be under an occupational pension scheme with probability of $90 \%$. All in all, we labelled this class as the "insider" group of the labour market based on their characteristics which have been defined as "insider" characteristics in the existing literature: those with secure stable employment, in highly skilled occupations and covered by occupational pensions, not in low pay. 
The next class, namely the "outsider" group tends to be distinguishable by their wage and occupation status as well as occupational pension coverage. All people in the outsider class seem to have low-pay work (with probability of 100\%) and are most likely to have a job in generally/vocationally skilled or low/unskilled class (total 93\%). This group can be also distinguished by their very low chance of being covered by an occupational pension programme with only $21 \%$ likelihood. Although the likelihood of having atypical contracts is much higher for this group compared to the first one (three times as likely to be in temporary employment and seven times more likely to be in involuntary part-time), in absolute terms, their likelihood of being in these positions are still very low. Most people in the group are likely to be in a permanent and full-time or voluntary-part-time job - 94 and 93 percent respectively. This is partly because there are a limited number of workers who are in the involuntary parttime or non-permanent employment in the UK labour market. Hence the employment contract types are unlikely to be the driving factor of defining insiders and outsiders in the UK compared to the other factors included in the model.

The third class groups people with the highest level of temporary contract status and lowest likelihood to be covered in the occupational pension scheme. This group is 1.6 times and 4.9 times more likely to be in temporary employment compared to the outsider class and the insider class respectively, although the absolute likelihood remains low at approximately $10 \%$. What is more distinguishable is their occupational pension coverage. The results show that workers in this group have almost no chance of having occupational pensions through their jobs. This makes us believe that this group is more insecure than the previous "outsider" groups in terms of future income and job security. On the other hand, they are more likely to be in better occupation statuses compared to the "outsider" group, with $1 / 3$ being in (associate) professional/managerial positions. In addition, most earn above the low-pay threshold (92\%) and very limited numbers $(3 \%)$ are in involuntary part-time contracts. Thus, this group may not be in a particularly vulnerable situation affecting the quality of their life immediately, but is likely to face dire consequences in their (distant) future due to income or job insecurities. Thus, we label this group as "future insecure" class.

Table 3. Results of item probabilities for a joint model across the time period between 1999 and 2010

\begin{tabular}{llccc}
\hline Item/Response & \multicolumn{1}{l}{$\begin{array}{l}\text { Response } \\
\text { items,conditional on class }\end{array}$} & probabilities & for & categories of \\
\cline { 2 - 4 } & Insider & Outsider & Future insecure \\
\hline Full-time and voluntary part-time workers & 0.99 & 0.93 & 0.97 \\
Involuntary part-time workers & 0.01 & 0.07 & 0.03 \\
\hline
\end{tabular}




\begin{tabular}{llll}
\hline Permanent workers & 0.98 & 0.94 & 0.91 \\
Non-permanent workers & 0.02 & 0.06 & $\mathbf{0 . 0 9}$ \\
\hline Non low-pay workers & $\mathbf{0 . 9 9}$ & 0.00 & 0.92 \\
Low- pay workers & 0.01 & $\mathbf{1 . 0 0}$ & 0.08 \\
\hline Professional/managerial & $\mathbf{0 . 3 1}$ & 0.01 & 0.15 \\
Associate professional/ managerial & $\mathbf{0 . 2 4}$ & 0.06 & 0.17 \\
Generally/vocationally skilled & 0.35 & $\mathbf{0 . 6 7}$ & 0.47 \\
Low/Unskilled & 0.10 & $\mathbf{0 . 2 6}$ & 0.21 \\
\hline Under pension scheme & $\mathbf{0 . 9 0}$ & 0.21 & 0.00 \\
Not belong to pension scheme & 0.10 & $\mathbf{0 . 7 9}$ & $\mathbf{1 . 0 0}$
\end{tabular}

Note: the numbers marked in bold indicate each group's distinctive characteristics with respect of the variables included in our analyses.

As mentioned in the methods section, the distribution of a latent class may not be stable over the different points. In other words, the pattern of divided labour segments can be represented differently dependent on cohort differences, particularly related to the economic conditions or institutional changes. Thus, the time covariant is included in the model to examine any changes in the distribution of latent classes over this period. The results show that there is a common ground with a relatively stable ratio of three labour segments, although some variations in the distribution of latent class are observed (Table 4). This means that there are some cohort differences since the distribution of latent groups has shown some changes across each time point, however, the overall pattern of the divide has remained relatively stable. The insiders who are represented with good job stability as well as income security account the largest proportion (45-60\%) while that of outsiders is the smallest among them (13-20\%). The 'future insecure' group situates in between the 'insider' and 'outsider' group (24-39\%). The distinctive characteristics of each labour segment also remain stable over time. Furthermore, the results of fit statistic shows that the average standardised residuals have improved to 27 by allowing for the cohort differences, i.e., time covariance. Thus, it is important to note that allowing the nonequivalence of measurement across the time points helps to improve the model fit and show the accurate proportion at each time point. ${ }^{8}$

Table 4. Estimated percentage in each class by year (\% of the total dependent employed)

\footnotetext{
${ }^{8}$ However, the two-way standardised residuals are still greater than 4.
} 


\begin{tabular}{llllll}
\hline Year & Outsider & Insider & $\begin{array}{l}\text { Future } \\
\text { insecure }\end{array}$ & $\begin{array}{l}\text { Total } \\
\text { N }\end{array}$ & $\begin{array}{l}\% \\
\text { employed }\end{array}$ \\
\hline 1999 & & & 32.7 & 7072 & 49.6 \\
2000 & 13.4 & 53.9 & 39.3 & 7168 & 50.1 \\
2001 & 15.0 & 45.7 & 25.3 & 7195 & 49.5 \\
2002 & 20.0 & 54.8 & 31.1 & 6990 & 50.5 \\
2003 & 15.0 & 53.9 & 29.3 & 6908 & 50.5 \\
2004 & 15.0 & 55.8 & 31.2 & 6885 & 51.0 \\
2005 & 15.5 & 53.3 & 31.5 & 6727 & 50.4 \\
2006 & 14.4 & 54.0 & 24.2 & 6617 & 50.0 \\
2007 & 15.6 & 60.2 & 28.7 & 6436 & 50.3 \\
2008 & 13.0 & 58.4 & 26.6 & 6199 & 49.8 \\
2010 & 12.6 & 60.8 & 24.8 & 4693 & 47.0 \\
\hline
\end{tabular}

\subsection{Robustness checks}

There are indications that our set of models tend to still have a poor model fit considering the results of the two-way standardised marginal residuals are greater than 4, despite allowing the time covariant. In this case, the poor model fit can be due to our measurement model which is derived from theoretical literature and deductive perspectives of labour market divisions. In other words, the observed variables (indicators) that we drew from the theoretical literature of dualized labour market patterns may not all be relevant in determining the labour market division for the specific case of the UK. The inclusion of irrelevant factors may indirectly affect our model fit. This is in line with the fact that we see little improvement of model fit when increasing the number of classes, as shown in Table 2.

According to the bivariate residuals, which provide an overall summary of how well a model fits the observed joint distributions of pairs of the observed items (Magidson and Vermunt 2003), most of the large values are due to the involuntary part-time variable. Having taken involuntary part-time out of our model, this increases the model fit drastically, with an average 2 percent standardized marginal residuals and 0 to 4 percent range conditional on time points. ${ }^{9}$ This suggests that, in the case of UK, involuntary part-time employment may not be a crucial indicator in explaining the dualized labour market patterns, leading to overall statistically poor fitting models. However, without the involuntary part-time variable, the model does not produce internally homogenous classes, which means in practice the item probability responses are not close to 0 or 1 . Such features do not provide a clear interpretation and distinctive

\footnotetext{
9 Due to the lack of space, we could not include the results of model fit statistics without involuntary part-time variable. But, all results can be provided upon the request. 
characteristics of each labour segment. This implies that although the proportion of involuntary part-time is relatively small and it tends to affect the poor model fit, it helps in evaluating the characteristics of the British labour market divisions of other factors clearer.

\section{Discussion and conclusion}

There has been an increase in literature that examines the patterns of dualization of labour market across different welfare states. However, rarely do these studies empirically explore how the labour market is divided. Rather they assume a certain type of division to exist in the market, and apply this assumption to measure the extent to which this division can be observed. What is more, too much emphasis is placed on the role of atypical employment to measure this division. One of the reasons for this is the focus given to the German and other Continental European/corporatist country cases, without much investigation to see whether this definition of labour market division can be applied to other countries. To address this issue, this paper uses latent class analysis models to empirically examine the patterns and characteristics of labour market division over the past decade in the UK. The results of this paper provide strong evidence to show that although dualization is prevalent outside the corporatist countries, its patterns are diverse and that main patterns of labour market division vary in different institutional settings.

The results show that the UK labour market is divided into three specific labour groups throughout the period of 1999 to 2010, e.g., the "insider", "outsider" and "future insecure" groups. The first group comprise of people with secure employment - full-time and permanent contracts, and stable incomes over the low-pay threshold. These workers are most likely to be (associate) professionals and managers and are likely to be covered by occupational pension schemes. This group is named "insiders" due to their job stability and income security in the labour market not only now but also in the future, based on their employment contracts and access to occupational pension entitlements. Another prominent group, "outsiders", is likely to be in low-pay and in either generally/vocationally skilled or low/unskilled occupations. The majority of outsiders are unlikely to have an occupational pension through their work. In terms of employment contracts, although workers in the "outsider" class have a relatively higher chance of being in involuntary part-time employment and non-permanent employment, these features are not as distinctive as the other aspects such as income level, occupational profile, or occupational pension coverage. This group is unlikely to have security at the moment, but also in the future. The third group, namely the "future insecure" class is less likely to be in lowpay and involuntary part-time employment, but are more likely to be in temporary employment without occupational pension even compared to the "outsider" group. In other words, this group may have stability in their jobs and income now, but this may not persist in the future due to their lack of income security through pensions and the instability of their employment contracts. Thus, we conclude that there is a clear presence of groups representing the insiders and 
outsiders in the UK labour market. While a third group is found, we believe the biggest distinction between the groups is the division found between the "insider" group and others. Thus, the "outsider" and "future insecure" groups can both be in a way considered as two different types of "outsiders" while the "insider" group clearly has superior levels of employment stability and income security for both now and the future. Examining the changes in the proportion of each segment in the labour market over the past decade we find that, unlike what has been posited in the dualization theory, it is rather stable with relatively minor changes. Although the proportion of the "outsider" group has increased slightly in 2010, it is hard to verify exactly without further analysis whether it is directly related to economic crisis.

The significant contribution of this study to the existing literature on dualization, is that the divide between insiders and outsiders does not depend purely on the atypical contract status of the workers. At least in the UK, the main aspects that divide the workforce are rather wage levels, occupational positions, and access to occupational welfare. In other words, employment contract statuses, commonly used as the main factors in dividing the workforce in the main dualization literature for corporatist and social democratic countries (e.g. Rueda 2005; Emmenegger et al. 2012a), do not necessarily play a big role in the division of the labour force in other countries. What is more, some of the atypical employment characteristics, particularly the involuntary part-time variable, are the main factor causing the poor fit of our model, confirmed by improved statistical fit indices when removed. Previous studies have also argued that there are cross-national differences to what constitutes as the outsider group, as well as who belongs to it (Esping-Andersen 1990; Davidsson and Naczyk 2009), and that dualization patterns vary across countries, time and policy areas (Emmenegger et al. 2012a). However, this paper is one of the first to provide concrete empirical evidence to show exactly how the divided groups can be characterised using individual level data across time. Due to the scope of the paper, we have only been able to include data from Britain. Nevertheless, future research should examine other country cases in order to explore and compare empirically driven labour market division patterns across countries, to help, support or develop the literature on labour market divisions and the dualization literature. We find that latent class analysis techniques provide valuable analysis capabilities that help us understand labour market divisions better than some of the previous methods applied and this methods should be explored further in future studies. Lastly, we have not been able to explain which individuals are more likely to be insiders or outsiders, nor have we been able to examine the stability/mobility patterns within and across these labour market segments. Further analysis as these can help us better understand the variety of labour market divisions and ensure these understandings are supported empirically. 


\section{Reference}

Bartholomew, D. J., Steele, F., Moustaki, I., \& Galbraith, J. (2008). The Analysis of Multivariate Social science Data Chapman \&Hall/CRC: Taylor \& Francis.

Bennett, F. (2014). The "Living Wage', Low Pay and in Work Poverty: Rethinking the Relationships. Critical Social Policy, 34(1), 46-65.

Biegert, T. (2014). On the outside looking in? Transitions out of non-employment in the United Kingdom and Germany. Journal of European Social Policy, 24(1), 3-18.

Blake, D. (2004). The Impact of Wealth on consumption and retirement behaviour in the UK Applied Financial Economics, 14(8), 555-576.

Blanchflower, D. G., Oswald, A. J., \& Garrett, M. (1990). Insider Power in Wage Determination. NBER Working Paper No. 3179. Cambridge, MA: National Bureau of Economic Research.

Blossfeld, H.-P., \& Mayer, K. U. (1988). Labour Market Segmentation in the Federal Republic of Germany: An Empirical Study of Segmentation Theories From a Life Course Perspective. European Sociological Review, 4(2), 123-140.

Bonoli, G. (2007). Time Matters: Postindustrialization, New Social Risks, and Welfare State Adaptation in Advanced Industrial Democracies Comparative Political Studies, 40(5), 495-520.

Booth, A. L., Francesconi, M., \& Frank, J. (2002). Temporary jobs: Stepping stone or dead ends? . Economic Journal, 112(480), F189-F213.

Bradshaw, J., Bennett, F., \& Mayhew, E. (2010). In-Work Poverty and Labour Market Segmentation: A Study of National Policies. European Commission, DG Employment, Social Affairs and Inclusion: Brussels.

Branden, J. (2009). How Much Can We Learn From International Comparisons Of Intergenerational Mobility? (pp. DP111). Centre for Economic Performance, London School of Economics.

Bulow, J. I., \& Summers, L. H. (1986). A Theory of Dual Labor Markets with Application to Industrial Policy, Discrimination and Keynesian Unemployment. Journal of Labor Economics, 4(3), 376-414.

Cappellari, L. (2002). Do the 'Working Poor' Stay Poor?: An analysis of Low-Pay Transition in Italy Oxford Bulletin of Economics and Statistics, 64(2), 89-110. 
Cappellari, L., \& Jenkins, S. P. (2004). Modelling Low Pay Transitions Probabilies, Accounting for Panel Attrition, Non-response and Initial Conditions. Working Paper 2004-08. Institute for Social and Economic Research, University of Essex, Colchester

Chung, H. (2005). Different paths towards flexibility: Deregulated employment protection or temporary employment: A study of cross-national variance on employment protection legislation and temporary employment in 19 OECD countries. Paper presented at the the ESPAnet 2005 annual conference: Making Social Policy in the post-industiral age, University of Fribourg, Switzerland,

Chung, H. (2013). Mind the gap: Impact of labour market institutions on the insecurity inequalities between insiders and outsiders. Paper presented at the the ESPAnet annual conference, Poznan University of Economics, Poznan, Poland,

Chung, H., Kerkhofs, M., \& Ester, P. (2007). Working time flexibility in European companies. Luxembourg: European Foundation for the Improvement of Living and Working Conditions.

Coe, D. T. (1990). Insider-Outsider Influences on Industry Wages. Empirical Economics, 15(2), p.163-183.

Davidsson, J., \& Emmenegger, P. (2013). Defending the Organisation, Not the Members: Unions and the Reform of Job Security Legislation in Western Europe European Journal of Political Research, 52(3), 339-363.

Davidsson, J., \& Naczyk, M. (2009). The Ins and Outs of dualisation: A Literature Review. RECWOWE Working paper 2 Edniburgh: Reconciling Work and Welfare in Europe (RECWOWE).

Deakin, S., \& Reed, H. (2000). River Crossing or cold Bath? Deregulation and Employment in Britain in the 1980s and 1990s. In G. Esping-Andersen, \& M. Regini (Eds.), Why Deregulate Labour Market? (pp. 115-147). Oxford Oxford University Press.

Dean, N., \& Raftery, A. E. (2010). Latent Class Analysis Variable Selection Annals of the Institute of Statistical Mathmatics, 62(1), 11-35.

Doeringer, P., \& Piore, M. (1971). Internal labour Markets and Manpower Analysis. Lexington Mass: D.C. Heath.

Dolado, J. J., Garcia-Serrano, C., \& Kimeno, J. F. (2002). Drawing Lessons From the Boom of Temporary Jobs in Spain. The Economic Journal, 112(480), 270-295.

Eichhorst, W., \& Marx, P. (2011). Reforming German Labor Market Institutions: A Dual Path 23 
to Flexibility. Journal of European Social Policy, 21(1), 73-87.

Elias, P. (1997). Restructuring, Reskilling and Redundancy: A Study of Dynamics of the UK Labour Market, 1990-1995. ISER Working Paper Series,

Emmenegger, P., Häusermann, S., Palier, B., \& Seeleib-Kaiser, M. (Eds.). (2012a). The Age of Dualization: The Chaning Face of Inequality in Deindustrializing Societies. Oxford: Oxford University Press.

Emmenegger, P., Häusermann, S., Palier, B., \& Seeleib-Kaiser, M. (2012b). How We Grow Unequal. In P. Emmenegger, S. Häusermann, B. Palier, \& M. Seeleib-Kaiser (Eds.), The Age of Dualization: The Changing Face of Inequality in Deindustrializing Socieites (pp. 3-26). New York: Oxford University Press.

Esping-Andersen, G. (1990). The Three Worlds of Welfare Capitalism. Princeton, New Jersey: Princeton University PRess.

Esping-Andersen, G. (1999). Social Foundations of Postindustrial Economies Princeton, NJ: Princeton University Press.

Ferragina, E., \& Seeleib-Kaiser, M. (2011). Welfare Regime Debate: Past, Present, Futures? . Policy \& Politics, 39(4), 583-611.

Ferragina, E., Seeleib-Kaiser, M., \& Sprecklesen, T. (2015). The Four Worlds of 'Weflare Reality'- Social Risks and Outcomes in Europe Social Policy and Society, 14(2), 287307.

Gebel, M. (2010). Early Career consequences of Temporary Employment in Germany and the UK work. Employment \& Society, 24(4), 641-660.

Gerber, M., Wittekind, A., Grote, G., \& Staffelbach, B. (2009). Exploring Types of Career Orientation: A Latent Class Analysis Approach. Journal of Vocational Behaviour, 75(3), 303-318.

Goos, M., \& Manning, A. (2003). Lousy and Lovely Jobs: The Rising Polarization of Working in Britain. Discussion Paper 604: Centre for Economic Performance, London School of Economics and Political Science.

Gordon, D. M., Edwards, R. C., \& Reich, M. (1982). Segmented Work, Divided Workers: The historical transformation of labor in the United States. Cambridge: Cambridge University Press.

Green, F. (2007). Temporary Work and Insecurity in Britain: A Problem Solved? . Social Indicators Research, 88(1), 147-160. 
Gregg, P. (1997). Jobs, Wages and Poverty: Patterns of Persistence and Mobility in the Flexible Labour Market. Centre for Economic Performance, LSE.

Gregg, P., \& Wadsworth, J. (2011). The Labour Market in Winter- The 2008-2009 Recession. In P. Gregg, \& J. Wadsworth (Eds.), The Labour Market in Winter: The State of Working Britain (pp. 9-21): Oxford University Press.

Häusermann, S., \& Schwander, H. (2009). Indentifying Outsiders Across Countires: Similarities and Differences in the patterns of Dualization The Reconciliation of Work and Welfare in Europe (Vol. 09/2009). Edinburgh: RECWOWE Publication

Häusermann, S., \& Schwander, H. (2012). Varieties of Dualization? Labor Market Segmentation and Insider-Outsider Divides Across Regimes. In P. Emmenegger, S. Häusermann, B. Palier, \& M. Seeleib-Kaiser (Eds.), The Age of Dualization: The Changing Face of Inequality in Deindustrializing Societies (pp. 27-51). Oxford: Oxford University Press.

Hall, P. A., \& Soskice, D. (2001). Varieties of Capitalism: The Institutional Foundations of Comparative Advantage. Oxford: Oxford University Press.

ILO (2012). International Standard classification of Occupations: ISCO-08. Geneva: International Labour Office

Jenkins, S. P. (2010). The British Household Panel Survey and its Income Data ISER Working Paper Series, No. 2010-33, Institute for Social and Economic Research

Jessoula, M., Graziano, P. R., \& Madama, I. (2010). 'Selective Flexicurity' in Segmented Labour Markets: The Case of Italian 'Mid-Siders'. Journal of Social Policy, 39(4), 561583.

Kalleberg, A. L. (2009). Precarious Work, Insecure Workers: Employment Relations in Transition. American Sociological Review, 74(1), 1-22.

Kerkhofs, M., Chung, H., \& Ester, P. (2008). Working time flexibility across Europe: A typology using firm-level data Industrial Relations Journal, 39(6), 569-585.

Kolev, A., \& Saget, C. (2010). Are Middle-Paid Jobs in OECD Countries Disappearing? An Overview. Geneva,

Lee, Y.-H., Cheng, C.-Y., \& Lin, S. S. J. (2014). A Latent Profile Analysis of Self-Control and Self-Esteem and the Grouping Effect on Adolescent Quality of Life Across the Two Consecutive Years. Social Indicators Research, 117(2), 523-539.

Leontaridi, M. (1998). Segmented Labour Markets: Theory and Evidence journal of Economic 25 
Surveys, 12(1), 103-109.

Lindbeck, A., \& Snower, D. (1986). Wage Setting, Unemployment and Insider-Outsider Relations. American Economic Review, 76(2), 235-239.

Lindbeck, A., \& Snower, D. (1988). The Insider-Outsider Theory of Employment and Unemployment Cambridge, Mass: MIT Press.

Lindbeck, A., \& Snower, D. (2001). Insiders versus Outsiders. Journal of Economic Perspectives, 15(1), 165-188.

Lindbeck, A., \& Snower, D. (2002). The Insider-Outsider Theory: A Survey. IZA Discussion Paper, No.534.

Little, R. J., \& Rubin, D. B. (2002). Statistical Analysis with Missing Data: John Wiley \& Sons Machin, S. (2011). Changes in UK Wage Inequality Over the Last Forty Years. In P. Gregg, \& J. Wadworth (Eds.), The Labour Market in Winter : The state of Working Britain (pp. 155-169): Oxford University Press.

Magidson, J., \& Vermunt, J. K. (2003). Latent Class Models. In D. Kaplan (Ed.), The Sage Handbook of Quantitative Methodology for the Social Sciences (pp. 175-198). Thousand Oaks: Sage Publication.

Marsden, D. (2007). Labour Market Segmentation in Britain: The Decline of Occupational Labour Markets and the Spread of 'Entry Tournaments'. Économies et Sociétés, 28, $965-$ 998.

McCutcheon, A. L. (1987). Latent Class Analysis: Sage

Mejlgaard, N., \& Stares, S. (2012). Performed and preferred participation in sicence and technology across Europe: Exploring an alternative idea of "democratic deficit". Public Understanding of Science, 22(6), 660-673.

Muthén, L. K., \& Muthén, B. O. (1998-2010). Mplus User's Guide (Sixth Edition). Los Angeles, CA: Muthén \& Muthén

Nylund, K. L., Asparouhov, T., \& Muthén, B. O. (2007). Deciding on the Number of Classes in Latent Class Analysis and Growth Mixture Modeling: A Monte Carlo Simulation Study. Structural Equation Modeling, 14(4), 535-569.

OECD (1999). Employment Protection Regulation and Labour Market Performance In OECD (Ed.), OECD Employment Outlook (pp. 48-132). OECD publishing.

OECD (2004). Employment Protection Regulation and Labour Market Performance. In OECD (Ed.), OECD Employment Outlook (pp. 61-125). Paris: OECD publishing. 
OECD (2008). Growing Unequal? Income Distribution and Poverty in OECD countries. Paris: OECD Publishing.

OECD (2011). Divided We Stand: Why Inequality keeps Rising. Paris: OECD publishing.

OECD (2013). OECD Employment Outlook 2013. Paris: OECD publishing

Palier, B., \& Thelen, K. (2012). Dualization and Institutional Complementarities: Industrial Relations, Labor Market and Welfare State Changes in France and Germany. In P. Emmenegger, S. Häusermann, B. Palier, \& M. Seeleib-Kaiser (Eds.), The Age of Dualization: The Changing Face of Inequality in Deindustrializing Societies (pp. 201225). Oxford: Oxford University Press.

Palier, B., \& Thelen, K. A. (2010). Institutionalizing Dualism: Complementarities and change in France and Germany. Politics and Societies, 38(1), 119-148.

Pavlopoulos, D. (2013). Starting Your Career With a Fixed-Term Job: Stepping-Stone or "Dead-End'? . Review of Social Economy, 71(4), 474-501.

Pavlopoulos, D., Muffels, R., \& Vermunt, J. K. (2012). How Real is Mobility between Low Pay, High Pay and Non-employment? Journal of the Royal Statistical Society Series A, 175(3), 749-773.

Pennycook, M., \& Whittaker, M. (2012). Low Pay Britain 2012. London: Resolutation Foundation

R Core Team (2014). R: A language and environment for statistical computing. R Foundation for Statistical Computing, Vienna, Austria, 2012.

Reich, M., Gordon, D. M., \& Edwards, R. C. (1973). Dual labour market: A theory of labor Market Segmentaiton. American Economic Review, 63(2), 359-365.

Rose, R. A., Parish, S. L., \& Yoo, J. P. (2009). Measuring Material Hardship among the US Population of Women with Disabilities Using Latent Class Analysis Social Indicators Research, 94(3), 391-415.

Rueda, D. (2005). Insider-Outsider Politics in Industrialized Democracies: The challenge to Social Democratic Parties American Political Science Review, 99(1), 61-74.

Rueda, D. (2006). Social Democracy and Active Labour Market Policies, Insiders, Outsiders and the Politics of Employment Protection. British Journal of Political Science, 36(3), 385-406.

Rueda, D. (2007). Social Democracy Inside Out: Partisanship and Labour Market Policy in Advanced Industrial Democracies Oxford New York: Oxford University Press. 
Rueda, D. (2012). Dualization and Crisis. Swiss Political Science Review, 18(4), 523-530.

Rueda, D. (2014). Dualization, Crisis and the Welfare State. Socio-Economic Review, 12(2), 381-407.

Schwander, H. (2010). Assessing the Extent of Dualization: Differences in Pension Coverage between Insiders and Outsiders in Britain, Switzerland and Sweden. Paper presented at the Swiss Political Science Association, University of Geneva,

Schwander, H., \& Häusermann, S. (2011). Explaining welfare preferences in dualized societies Paper presented at the Joint Doctoral Seiminar of Oxford and Sicence Po, Paris, May 25-26, 2011,

Schwander, H., \& Häusermann, S. (2013). Who is in and who is out? A risk-based Conceptualization of insiders and outsiders. Journal of European Social Policy, 23(3), 248-270.

Seeleib-Kaiser, M., Saunders, A., \& Naczyk, M. (2012). Shifting the Public -Private Mix: A New Dualization of Welfare In P. Emmenegger, S. Häusermann, B. Palier, \& M. Seeleib-Kaiser (Eds.), The Age of dualization: The Chaning Face of Inequality of Deinstrializing Societies (pp. 151-175). Oxford Oxford University Press.

Sloane, P. J., \& Theodossiou, I. (1996). Earning Mobility, Family Income and Low Pay Economic Journal, 106(436), 657-666.

Sloane, P. J., \& Theodossiou, I. (1998). An Econometic Analysis of Low Pay and Earnings Mobility in Britain In R. Asplund, \& P. J. Sloane (Eds.), Low Pay and Earnings Mobility in Europe Cheltenham: Edward Elgar Publishing

Standing, G. (2011). The Precariat: The New Dangerous Class London and New York: Bloomsbury.

Taylor, M. F., Brice, J., Buck, N., \& Prentice-Lane, E. (Eds.). (2010). British Household Panel Survey User Manual Volume A: Introduction, Technical Report and Appendices. Colchester: University of Essex.

Tomlinson, M., \& Walker, R. (2012). Labour Market Disadvantage and the Experience of Recurrent Poverty. In P. Emmenegger, S. Häusermann, B. Palier, \& M. Seeleib-Kaiser (Eds.), The Age of Dualization: The Changing Face of Inequality in Deindustrializing Societies (pp. 52-72): Oxford University Press.

University of Essex (2013). Understanding Society: The UK Household Longitudinal Study Wave 1-3, User Manual. Colchester University of Essex. 
Vallas, S., \& Prener, C. (2012). Dualism, Job Polarization, and the Social Construction of Precarious Work. Work and Occupations, 39(4), 331-353.

Van Aerden, K., Moors, G., Levecque, K., \& Vanroelen, C. (2014). Measuring Employment Arrangements in the European Labour Force" A typological Approach. Social Indicators Research, 116(3), 771-791.

Van Kersbergen, K., \& Vis, B. (2013). Comparative Welfare State Politics: Cambridge University Press. 


\section{Appendix 1.}

Specification of the model

The basic latent class model can be specified as follows:

Let $j=1, \ldots, J$ observed variable, and observed variable $j$ has $r_{j}=1, \ldots, R_{j}$ response categories. $L$ is categorical latent variable with $c=1, \ldots, C$ latent classes. We model the probabilities of belonging to class $\mathrm{c}$ as $\gamma_{c}$ and the item-response probabilities of objected variable $j$ is referred to as $\rho_{j}$.

As the latent classes are mutually exclusive and exhaustive, each individual is a member of one and only one latent class. Thus,

$$
\sum_{c=1}^{\mathrm{C}} \gamma_{c}=1
$$

Also, each individual provides one and only one response alternative to variable $\mathrm{j}$, the vector of item-response probability $\rho_{j}, \gamma_{j} \mid c$ (the probability of response $\gamma_{j}$ to observed variable $j$, conditional on membership in latent class c) always sums to 1 . Therefore,

$$
\sum_{r_{j}}^{\mathrm{R}_{\mathrm{j}}} \rho_{j,} \gamma_{j} \mid c=1
$$

Suppose $\mathcal{Y}_{j}$ representing element $j$ of a response pattern $\mathbf{y}$. We model an indicator function $I$ $\left(\mathcal{Y}_{j}=\gamma_{j}\right)$ that equals 1 when the response of variable $j=\gamma_{j}$, and otherwise equals 0 . Then equation of how the probability of observing a particular vector of response is a function of the probabilities of membership in each latent class (the $\gamma$ ) and the probabilities of observing each response conditional on latent class membership: ,

$$
P(Y=\mathrm{y})=\sum_{c=1}^{C} \gamma_{c} \prod_{j=1}^{J} \prod_{\gamma_{j=1}}^{R_{j}} \rho_{j, r_{j} \mid c}^{I\left(y_{j}=\gamma_{j}\right)}
$$


The equation of the probability of a particular observed response pattern y conditional on membership in a particular latent class $c$ is,

$$
P(Y=\mathrm{y} \mid L=c)=\sum_{c=1}^{C} \gamma_{c} \prod_{j=1}^{J} \prod_{\gamma_{j=1}}^{R_{j}} \rho_{j, r_{j} \mid c}^{I\left(y_{j}=\gamma_{j}\right)}
$$

The next step, after computing the conditional response probabilities for each latent class $c$, is to obtain the unconditional joint probabilities of latent class $\mathrm{c}$ and response pattern $\mathrm{y}, \mathrm{P}(\mathrm{Y}=\mathrm{y}$, $\mathrm{L}=\mathrm{c})$, for each of the $\mathrm{C}$ latent classes. The equation for this is,

$$
P(\mathrm{Y}=\mathrm{y}, L=c)=P(L=c) P(Y=y \mid L=c)=\gamma_{c} \prod_{j=1}^{J} \prod_{\gamma_{j=1}}^{R_{j}} \rho_{j,} \gamma_{j} \mid c^{I\left(y_{j}=\gamma_{j}\right)}
$$

In terms of conducting the multiple group latent class models, we introduce a group variable $V$ with $q=1, \ldots, Q$ groups. In our paper, $V$ represents cohorts and there are $Q=11$ groups: total dependent employees in BHPS from 1999 to 2010. Each response pattern y corresponding to cohort $\mathrm{q}$ is related with a probability of occurrence $P(\mathrm{Y}=\mathrm{y} \mid V=q)$, and within each time point $1, \sum P(\mathrm{Y}=\mathrm{y} \mid V=q)=1$. Thus, the equation of conditional membership in latent class $\mathrm{c}$ and group $\mathrm{q}$ is,

$$
P(\mathrm{Y}=\mathrm{y} \mid V=q)=\sum_{c=1}^{C} \gamma_{c \mid q} \prod_{j=1}^{J} \prod_{\gamma_{j=1}}^{R_{j}} \rho_{j}, \gamma_{j} \mid c, q^{I\left(y_{j}=\gamma_{j}\right)}
$$


Appendix Table 1. Classification of occupation, based on ILO's ISCO-08 (2012) and Schwander and Häusermann(2013)

\begin{tabular}{|c|c|}
\hline \multicolumn{2}{|l|}{ Occupation categories } \\
\hline \multirow[t]{5}{*}{ Professional/managerial } & 11 Legislators and Senior officials \\
\hline & 12 corporate Mangers \\
\hline & $\begin{array}{l}21 \text { Physical, mathematical and engineering science } \\
\text { professionals }\end{array}$ \\
\hline & 22 Life science and health professionals \\
\hline & 23 teaching professionals \\
\hline \multirow{6}{*}{$\begin{array}{l}\text { Associate } \\
\text { professional/managerial }\end{array}$} & 13 General Managers \\
\hline & 24 Other professionals \\
\hline & 31 Physical and engineering science associate professionals \\
\hline & 32 Life science and health associate professionals \\
\hline & 33 Teaching associate professionals \\
\hline & 34 Other associate professionals \\
\hline \multirow{8}{*}{$\begin{array}{l}\text { Generally/vocationally } \\
\text { skilled }\end{array}$} & 41 Office clerks \\
\hline & 42 Customer service clerks \\
\hline & 51 Personal and protective services workers \\
\hline & 52 Sales and services elementary occupations \\
\hline & 71 Extraction and building trade workers \\
\hline & 72 Metal, machinery and related trade workers \\
\hline & 73 Precision, handicraft, printing and related trades workers \\
\hline & 74 Other craft and related trade workers \\
\hline \multirow[t]{5}{*}{ Low/un-skilled } & 61 Market-oriented skilled agricultural and fishery workers \\
\hline & 62 Subsistence agricultural and fishery workers \\
\hline & 81 Stationary-plant and related operators \\
\hline & 91 Sales and service elementary occupation \\
\hline & 92 Agricultural, fishery and related labourers \\
\hline
\end{tabular}

